\title{
ROZDZIAt 9
}

\author{
Ewa Kusidet*, \\ Emilia Modranka**
}

\section{ZMIANY NA POLSKIM RYNKU PRACY PO AKCESJI DO UNII EUROPEJSKIEJ \\ I PRZYSZŁE KIERUNKI ZMIAN WYNIKAJACE Z DOKUMENTÓW STRATEGICZNYCH ORAZ ZMIAN DEMOGRAFICZNYCH}

\section{Wprowadzenie}

W niniejszym artykule przedstawiono główne tendencje na rynku pracy, jakie zaznaczyły się po wstapieniu Polski w struktury Unii Europejskiej. Badanie polskiego rynku pracy zostało dokonane $\mathrm{w}$ oparciu o analizę wskaźników monitorowanych w ramach dwóch głównych dokumentów strategicznych: Strategii Rozwoju Kraju 2007-2015 oraz Narodowych Strategicznych Ram Odniesienia 2007-2013.Celem artykułu jest zbadanie, czy obserwowane zmiany na rynku pracy są zgodne z kierunkami określonymi przez wskaźniki z dokumentów strategicznych (które wyznaczają kierunki rozwoju kraju) oraz sprawdzenie perspektyw ich przyszłej realizacji.

Jednym z głównych celów realizowanej Strategii Rozwoju Kraju jest wzrost zatrudnienia i podniesienie jego jakości, co ma następować w wyniku działań związanych z wyrównywaniem szans na rynku pracy, dostosowywaniem oferty edukacyjnej do potrzeb rynku, upowszechnianiem elastycznych form zatrudnienia, wzrostem mobilności zasobów pracy, jak również tworzeniem warunków sprzyjających przedsiębiorczości i zmniejszeniem obciążeń pracodawców ${ }^{1}$. Wydawać by się mogło, że realizacja tych celów

\footnotetext{
* Dr, Uniwersytet Łódzki, Katedra Ekonometrii Przestrzennej.

*** Mgr, Uniwersytet Łódzki, Katedra Ekonometrii Przestrzennej.

${ }^{1}$ Por. Strategia Rozwoju Kraju 2007-2015, Ministerstwo Rozwoju Regionalnego, Warszawa, listopad 2006.
} 
(skwantyfikowanych za pomocą wskaźników o których mowa w artykule) wiąże się głównie z określoną polityką rynku pracy i rozwojem gospodarczym. $\mathrm{W}$ artykule wskazano jednakże, że w osiaganiu zakładanych wartości niektórych wskaźników stosunkowo dużą rolę pełnią zmiany demograficzne. Wynika to z prognoz demograficznych, które wskazują na dość radykalne przeobrażanie się liczby i struktury ludności Polski, co może mieć niebagatelny wpływ na wybrane charakterystyki rynku pracy.

Artykuł podzielony jest na trzy rozdziały. W pierwszym omawiamy wartości i trendy wskaźników rynku pracy monitorowanych w analizowanych dokumentach strategicznych. Staramy się także odpowiedzieć na pytanie, czy kontynuacja, generalnie pozytywnych, tendencji zaobserwowanych w okresie po akcesji do Unii ${ }^{2}$ daje szanse na realizację celów w najbliższej przyszłości - roku 2013 i 2015. W rozdziale drugim analizujemy bieżącą i przyszłą strukturę demograficzną kraju, aby w rozdziale trzecim odpowiedzieć na pytanie, jaki może mieć ona wpływ na osiaganie celów zapisanych w dokumentach strategicznych.

\section{Kierunki zmian wskaźników rynku pracy z dokumentów strategicznych}

Według stanu na koniec marca 2010 r. w Polsce obowiązywały dwa główne dokumenty strategiczne ${ }^{3}$ :

- Strategia Rozwoju Kraju 2007-2015 (SRK) - średniookresowa strategia rozwoju kraju określająca kierunki rozwoju społeczno-gospodarczego, stanowiąca punkt odniesienia zarówno dla innych strategii i programów rządowych, jak i opracowywanych przez jednostki samorządu terytorialnego.

\footnotetext{
${ }^{2}$ Rodzi się naturalne pytanie, jaka część z ewidentnej poprawy sytuacji na polskim rynku pracy widocznej po akcesji do Unii jest konsekwencją tego faktu i realizowanej w związku z tym polityce spójności. Problematyce tej poświęcone były inne badania autorek, których wyniki można znaleźć w: J. Drążkiewicz i in., Wptyw interwencji $z$ funduszy strukturalnych UE na zatrudnienie, MRR, Warszawa 2007; J. Drążkiewicz i in., The impact of Cohesion Policy on the level and quality of employment in Poland, MRR, Warszawa 2010; J. Drążkiewicz i in., The impact of Cohesion Policy on the level and quality of employment in countries of the Visegrad Group, MRR, Warszawa 2011, czy E. Kusideł, Metody oceny wptywu funduszy strukturalnych na zatrudnienie, [w:] Unia Europejska w gospodarce światowej, J. Bilski (red.), Wydawnictwo Uniwersytetu Łódzkiego, Łódź 2007, E. Kusideł, The Impact of the Cohesion Policy on Poland's Economic Development, "Folia Acta Universitas Lodziensis. Folia Oeconomica", Wydawnictwo Uniwerstytetu Łódzkiego, Łódź 2011 - praca złożona do druku. Chcąc trzymać się głównego celu niniejszej pracy oraz sprostać reżimowi objętości tekstu, autorki postanowiły opuścić wątki związane z wpływem polityki spójności na rynek pracy.

${ }^{3}$ http://www.mrr.gov.pl/rozwoj_regionalny/Polityka_rozwoju/System_zarzadzania_rozwojem/ Dokumenty_strate giczne/Documents/Dokumenty_obowiazujace_marzec2010.pdf.
} 
- Narodowa Strategia Spójności 2007-2013 (nazwa urzędowa: Narodowe Strategiczne Ramy Odniesienia - NSRO) wspierająca wzrost gospodarczy i zatrudnienie. Dokument powstał na podstawie wytycznych UE określających główne cele polityki spójności z uwzględnieniem uwarunkowań społeczno-gospodarczych Polski ${ }^{4}$.

Analizę zmian na polskim rynku pracy przeprowadzono $\mathrm{w}$ oparciu o wskaźniki rynku pracy monitorowane w wyżej wymienionych dokumentach strategicznych, pogrupowane wg obszarów tematycznych ${ }^{5}$. Badanie zmian wybranych zmiennych jest prowadzone w dwóch okresach badawczych: latach 2004-2010 (okres po wstapieniu do Unii - którego analiza wynika z tematyki referatu określonej w jego tytule) i latach 1997-2003 (analogiczny okres poprzedzający, pozwalający stwierdzić na ile trendy zaobserwowane $\mathrm{w}$ tym okresie są różne od okresu po akcesji). Pomimo, że nazwy wymienionych powyżej dokumentów sugeruja, że obowiązują one dopiero od roku 2007 (a artykuł traktuje o zmianach od roku 2004), to uwzględniono w nich wcześniejsze wartości wskaźników ${ }^{6}$.

\subsection{Struktura pracujacych w trzech sektorach gospodarki}

Zgodnie z trójsektorową koncepcją struktury gospodarczej wraz ze wzrostem poziomu rozwoju i nowoczesności gospodarek zwiększa się udział zatrudnienia w usługach, kosztem przemysłu i przede wszystkim, rolnictwa ${ }^{7}$. Rolę zmian struktury zatrudnienia $w$ gospodarce polskiej oceniono na tyle wysoko, że odpowiednie wskaźniki znalazły swoje odzwierciedlenie w najważniejszych dokumentach strategicznych - por. 1.1a.

\footnotetext{
${ }^{4}$ Poprzednikiem tego dokumentu z poprzedniego okresu programowania był Narodowy Plan Rozwoju 2004-2006, który nawiązywał do Strategii Gospodarczej Rządu (przyjętej w 2002 r.).

5 Wskaźniki monitorowane $\mathrm{w}$ ramach obu strategii można znaleźć na stronie GUS: http://www.stat.gov.pl/gus/wskazniki_monitorujace_PLK_HTML.htm.

${ }^{6}$ Fundusze unijne z założenia mają być narzędziem wkomponowanym w plany rozwoju kraju i zasilającym istniejące już systemy polityk krajowych. Dlatego perspektywa przystapienie Polski do Unii wymusiła niejako powstanie takich planów (większość wcześniejszych polityk miało charakter sektorowy i nie posiadało funkcji strategicznych - por. K. Olejniczak, Rola ewaluacji w krajowych politykach publicznych - analiza systemowa lata 1999-2010, [w:] Ewaluacja w strategicznym zarzqdzaniu publicznym, A. Haber (red.), Polska Agencja Rozwoju Przedsiębiorczości, Warszawa 2010, s. 45.

${ }^{7}$ Por. E. Kwiatkowski, Teoria trzech sektorów gospodarki: prezentacja i próba oceny, PWN, Warszawa 1980.
} 


\section{Tabela 1.1a.}

Wskaźniki realizacji SRK (w ramach celu ogólnego) oraz NSRO (w ramach celu strategicznego: tworzenie warunków dla wzrostu konkurencyjności gospodarki opartej na wiedzy i przedsiębiorczości zapewniającej wzrost zatrudnienia oraz poziomu spójności społecznej) dotyczące struktury zatrudnienia w 3 sektorach gospodarki

\begin{tabular}{|l|l|l|l|l|l|l|l|l|l|l|}
\hline \multicolumn{1}{|c|}{ Wskaźnik } & 2004 & 2005 & 2006 & 2007 & 2008 & 2009 & 2010 & $\begin{array}{c}\text { SRK } \\
2010 \text { r. }\end{array}$ & $\begin{array}{c}\text { NSRO } \\
2013 \text { r. }\end{array}$ & $\begin{array}{c}\text { SRK } \\
2015 \text { r. }\end{array}$ \\
\hline $\begin{array}{l}\text { Struktura } \\
\text { pracujących } \\
\text { W sektorze I }\end{array}$ & 18,0 & 17,4 & 15,8 & 14,7 & 14,0 & 13,3 & 12,9 & 15,0 & 12,0 & 11,0 \\
\hline $\begin{array}{l}\text { Struktura } \\
\text { pracujących } \\
\text { W sektorze II }\end{array}$ & 28,8 & 29,2 & 30,0 & 30,8 & 31,9 & 31,1 & 30,2 & 27,5 & 26,0 & 26,0 \\
\hline $\begin{array}{l}\text { Struktura } \\
\text { pracujących } \\
\text { w sektorze III }\end{array}$ & 53,2 & 53,4 & 54,2 & 54,5 & 54,1 & 55,6 & 56,9 & 57,5 & 62,0 & 63,0 \\
\hline
\end{tabular}

Źródło: Strategia Rozwoju Kraju 2007-2015, Ministerstwo Rozwoju Regionalnego, Warszawa, listopad 2006, s. 25; Narodowe Strategiczne Ramy Odniesienia 2007-2013, wspierajace wzrost gospodarczy $i$ zatrudnienie, Ministerstwo Rozwoju Regionalnego, Warszawa, listopad 2006, ss. 71-74 lub http://www.stat.gov.pl/gus/wskazniki_monitorujace_PLK_HTML.htm.

Poniżej znajduje się wykres obrazujący zmiany, jakie zaszły w Polsce w strukturze zatrudnienia wg trzech sektorów gospodarczych w okresie po akcesji do Unii i w analogicznym okresie poprzedzającym. 


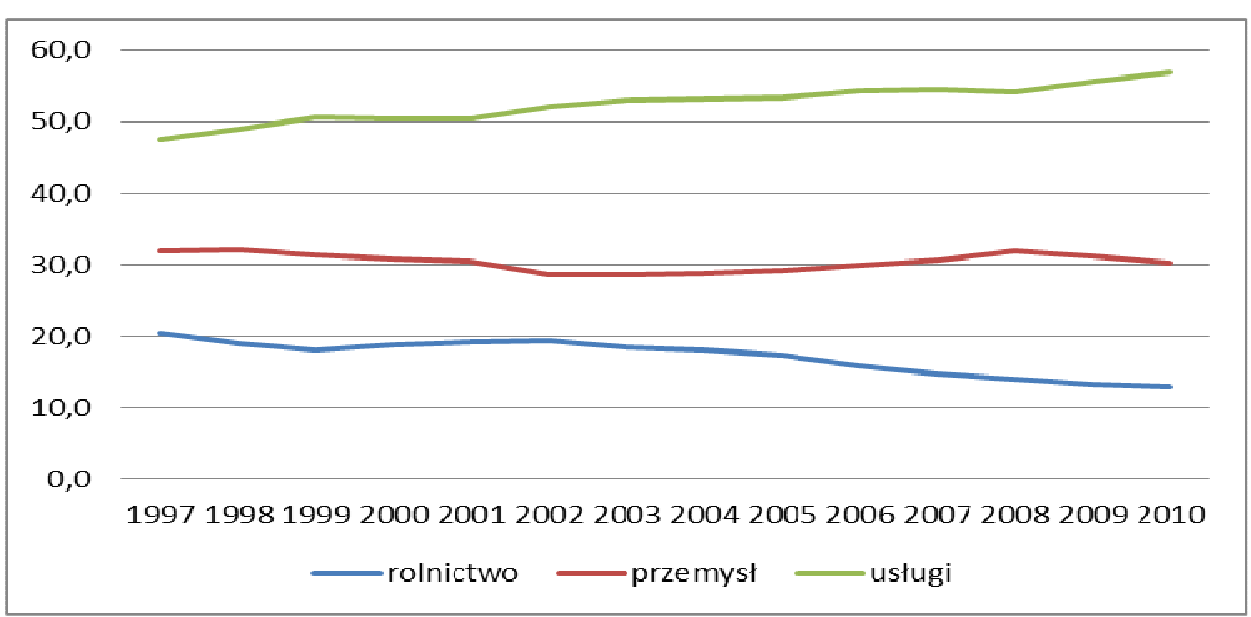

\section{Wykres 1.1. Struktura zatrudnienia w trzech sektorach gospodarki w okresie po przystąpieniu do Unii Europejskiej i analogicznym poprzedzającym $\mathrm{w}$ proc.}

Źródło: Opracowanie na podstawie Banku Danych Lokalnych.

Z powyższego wykresu wynika, że zmiany odsetka pracujących w rolnictwie były zdecydowanie silniejsze w okresie po akcesji do Unii. Średnioroczne tempo zmian było w tym wypadku zdecydowanie wyższe (co do wartości bezwzględnej) niż $\mathrm{w}$ analogicznym okresie poprzedzającym - por. tabela $1.1 \mathrm{~b}$. Tendencja ta spowodowała, że $\mathrm{w}$ roku 2010 odsetek zatrudnionych w rolnictwie był znacznie poniżej zakładanej na ten rok wartości w SRK (co, biorąc pod uwagę tendencje we wskaźnikach analizowanych dokumentów oraz teorię trzech sektorów, należy uznać za zjawisko pozytywne). Wolniejsze niż zakładano przemiany w II i III sektorze gospodarki spowodowały, że udział zatrudnienia w przemyśle przekracza, a w usługach nie osiaga wartości zakładanych w SRK (nie osiagnięto zamierzonych celów).

$\mathrm{W}$ tabeli $1.1 \mathrm{~b}$ pokazano średnioroczne tempo zmian analizowanych frakcji, wyliczone na podstawie wykładniczego trendu ${ }^{8}$, na podstawie którego (przy założeniu ekstrapolacji tendencji zaobserwowanych po akcesji do Unii ${ }^{9}$ ) dokonano wyliczeń badanych wskaźników w roku 2013 i $2015^{10}$.

\footnotetext{
${ }^{8}$ Taki sposób wyliczenia średniorocznych temp wzrostu zastosowano w całym artykule.

${ }^{9}$ Lata po akcesji do Unii pokrywają się z generalnie pozytywnymi tendencjami na rynku pracy. Dokonane ekstrapolacje zakładają więc, że te pozytywne tendencje będą się utrzymywać (choć należy również zauważyć, że okres będący podstawą ekstrapolacji zawiera również dane za 2009 i 2010 - lata, w których mogły uwidocznić się skutki kryzysu).

${ }^{10}$ Są to końcowe lata obowiązywania NSRO oraz SRK.
} 
Tabela 1.1b.

Średnioroczne tempa zmian (w proc.) wskaźników z tabeli 1.1a

\begin{tabular}{|l|c|c|}
\hline \multicolumn{1}{|c|}{ Wskaźnik } & $\begin{array}{c}\text { Średnioroczne } \\
\text { tempo zmian 1997-2003 }\end{array}$ & $\begin{array}{c}\text { Średnioroczne } \\
\text { tempo zmian 2004-2010 }\end{array}$ \\
\hline $\begin{array}{l}\text { Udział zatrudnionych } \\
\text { w sektorze I }\end{array}$ & $-0,8$ & $-5,8$ \\
\hline $\begin{array}{l}\text { Udział zatrudnionych } \\
\text { w sektorze II }\end{array}$ & $-2,1$ & 1,2 \\
\hline $\begin{array}{l}\text { Udział zatrudnionych } \\
\text { w sektorze III }\end{array}$ & 1,6 & 1,0 \\
\hline
\end{tabular}

Źródło: Opracowanie na podstawie tabeli 1.1a oraz Banku Danych Lokalnych.

Gdyby założyć utrzymanie się tempa wzrostu z lat 2004-2010 należy spodziewać się, że odsetek zatrudnionych w rolnictwie będzie niższy niż zakładana w dokumentach strategicznych wartość na rok 2013 i 2015 (co należy uznać za wykonanie ,ponadplanowe”). Nie zostaną natomiast osiagnięte wartości dla odsetka zatrudnionych w przemyśle i usługach - por. tabela 1.1c.

Tabela 1.1c.

Prognozowane (na podstawie ekstrapolacji funkcji trendu dla lat 2004-2010) wartości wskaźników $z$ tabeli 1.1a. oraz procentowe odchylenie prognozy od wartości zakładanej w dokumentach strategicznych

\begin{tabular}{|l|c|c|c|c|c|c|}
\hline \multicolumn{1}{|c|}{ Wskaźnik } & $\begin{array}{c}\text { Prognoza } \\
2013\end{array}$ & $\begin{array}{c}\text { Prognoza } \\
2015\end{array}$ & $\begin{array}{c}\text { NSRO } \\
2013 \mathrm{r} .\end{array}$ & $\begin{array}{c}\text { SRK } \\
2015 \mathrm{r} .\end{array}$ & $\begin{array}{c}\text { Różnica } \\
2013\end{array}$ & $\begin{array}{c}\text { Różnica } \\
2015\end{array}$ \\
\hline $\begin{array}{l}\text { Udział } \\
\text { zatrudnionych } \\
\text { w sektorze I }\end{array}$ & 10 & 8 & 12 & 11 & $-16 \%$ & $-27 \%$ \\
\hline $\begin{array}{l}\text { Udział } \\
\text { zatrudnionych } \\
\text { w sektorze II }\end{array}$ & 32 & 33 & 26 & 26 & $31 \%$ & $27 \%$ \\
\hline $\begin{array}{l}\text { Udział } \\
\text { zatrudnionych } \\
\text { w sektorze III }\end{array}$ & 58 & 59 & 62 & 63 & $-7 \%$ & $-6 \%$ \\
\hline
\end{tabular}

Źródło: Obliczenia własne na podstawie tabeli 1.1a. 


\subsection{Wskaźniki zatrudnienia w podziale na wiek i płeć}

Poniżej znajduje się tabela $\mathrm{z}$ wykazem wskaźników zatrudnienia monitorowanych w ramach dwóch głównych dokumentów strategicznych.

Tabela 1.2a.

\section{Wskaźniki dotyczące poziomu zatrudnienia monitorowane w ramach SKR i NSRO}

\begin{tabular}{|l|l|l|l|l|l|l|l|l|l|c|}
\hline \multicolumn{1}{|c|}{ Wskaźnik } & 2004 & 2005 & 2006 & 2007 & 2008 & 2009 & 2010 & $\begin{array}{c}\text { SKR } \\
2010 \text { r. }\end{array}$ & $\begin{array}{c}\text { NSRO } \\
2013 \text { r. }\end{array}$ & $\begin{array}{c}\text { SRK } \\
2015 \text { r. }\end{array}$ \\
\hline $\begin{array}{l}\text { Wskaźnik } \\
\text { zatrudnienia osób } \\
\text { w wieku 15-64 lata }\end{array}$ & 51,7 & 52,8 & 54,5 & 57,0 & 59,2 & 59,3 & 59,3 & 57,0 & 60,0 & 62,0 \\
\hline $\begin{array}{l}\text { Wskaźnik } \\
\text { zatrudnienia kobiet } \\
\text { w wieku 15-64 lata }\end{array}$ & 46,2 & 46,8 & 48,2 & 50,6 & 52,4 & 52,8 & 53,0 & 51,0 & 56,5 & 53,0 \\
\hline $\begin{array}{l}\text { Wskaźnik } \\
\text { zatrudnienia } \\
\text { mężczyzn } \\
\text { w wieku 15-64 }\end{array}$ & 57,2 & 58,9 & 60,9 & 63,6 & 66,3 & 66,1 & 65,6 & - & 63,5 & - \\
\hline $\begin{array}{l}\text { Wskaźnik } \\
\text { zatrudnienia osób } \\
\text { w wieku 55-64 lata }\end{array}$ & 26,2 & 27,2 & 28,1 & 29,7 & 31,6 & 32,3 & 34,0 & 31,0 & 35,0 & 37,0 \\
\hline $\begin{array}{l}\text { Wskaźnik } \\
\text { zatrudnienia osób } \\
\text { w wieku 55-64 lata } \\
\text { kobiety }\end{array}$ & 19,4 & 19,7 & 19,0 & 19,4 & 20,7 & 21,9 & 24,2 & - & 28,0 & - \\
\hline $\begin{array}{l}\text { Wskaźnik } \\
\text { zatrudnienia osób } \\
\text { w wieku 55-64 lata } \\
\text { mężczyźni }\end{array}$ & 34,1 & 35,9 & 38,4 & 41,4 & 44,1 & 44,3 & 45,3 & - & 45,0 & - \\
\hline
\end{tabular}

Źródło: Strategia Rozwoju Kraju 2007-2015, Ministerstwo Rozwoju Regionalnego, Warszawa, listopad 2006, s. 25; Narodowe Strategiczne Ramy Odniesienia 2007-2013, wspierajace wzrost gospodarczy i zatrudnienie, Ministerstwo Rozwoju Regionalnego, Warszawa, listopad 2006, ss. 71-74 lub http://www.stat.gov.pl/gus/wskazniki_monitorujace_PLK_HTML.htm.

${ }^{11}$ Wskaźniki zatrudnienia mierzą udział osób pracujących w danej grupie wiekowej w ogóle osób w tym wieku. 
Graficzne odzwierciedlenie dynamiki wskaźników z tabeli 1.2a. wraz $\mathrm{z}$ analogicznym okresem poprzedzającym pokazują poniższe wykresy.

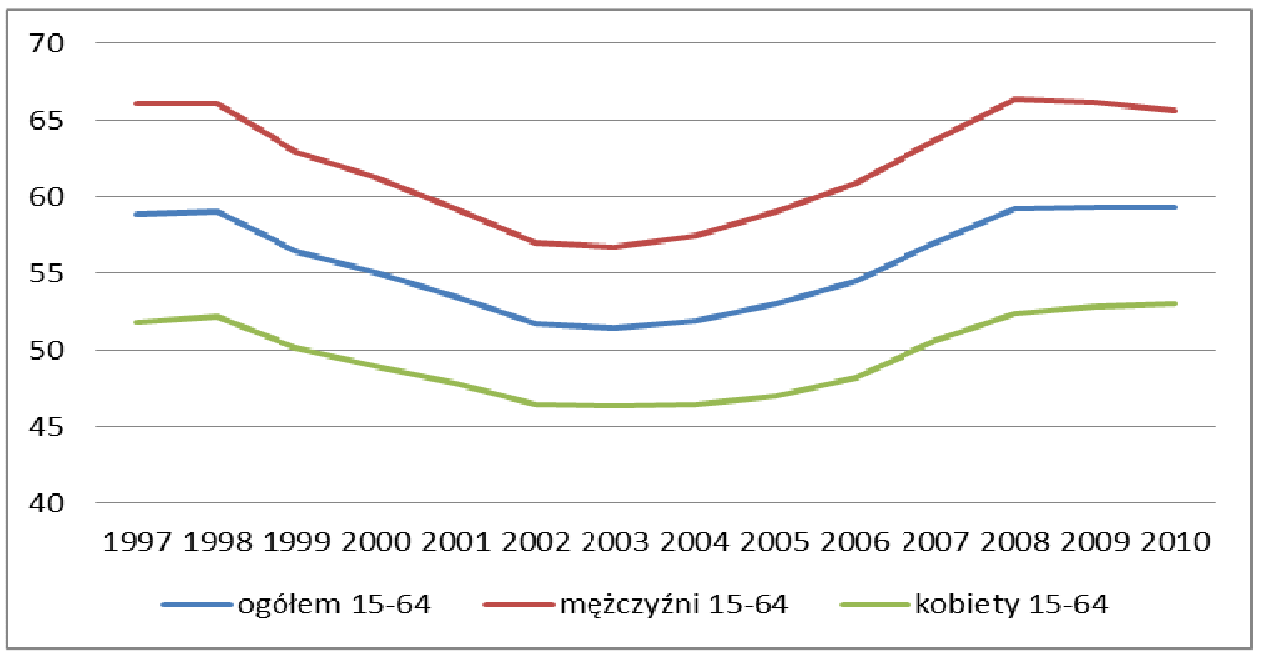

\section{Wykres 1.2a. Wskaźnik zatrudnienia osób w wieku 15-64}

Źródło: Opracowanie własne na podstawie danych z Banku Danych Lokalnych.

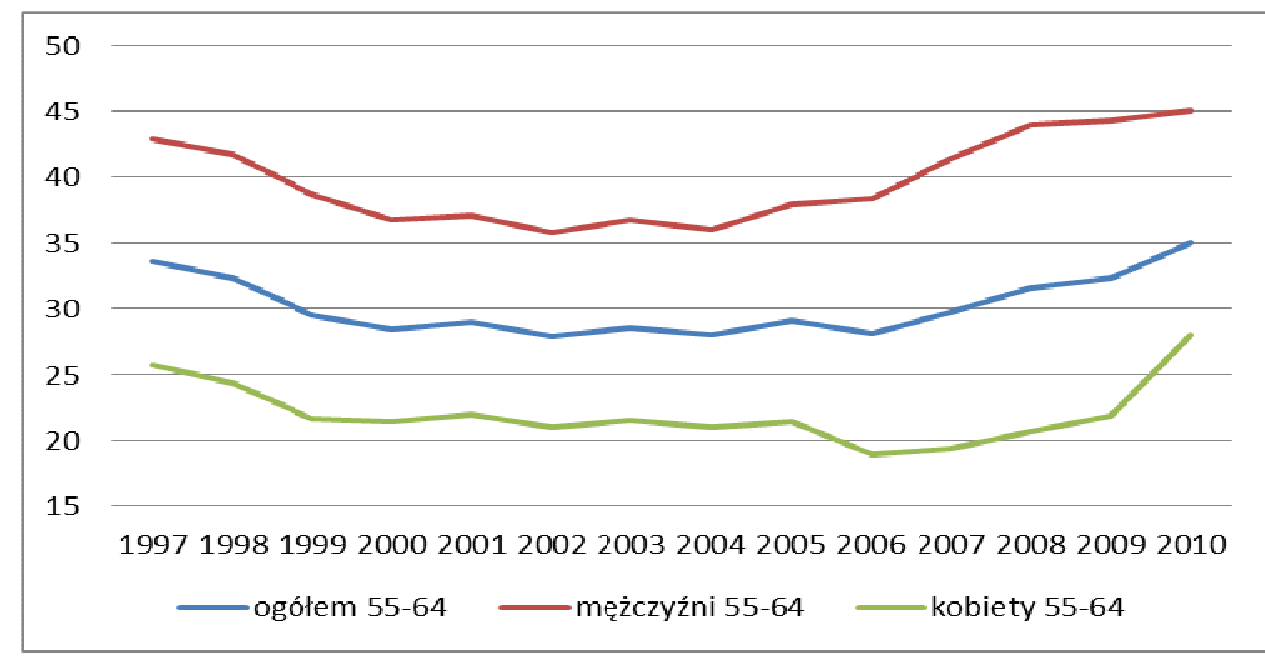

Wykres 1.2b. Wskaźnik zatrudnienia osób w wieku 55-64

Źródło: Opracowanie własne na podstawie danych z Banku Danych Lokalnych. 
Wykres wskaźnika zatrudnienia 15-64 bardzo dobrze obrazuje tendencje zatrudnieniowe na polskim rynku pracy: spadający, niemalże od początku transformacji ustrojowej w Polsce, wskaźnik zatrudnienia zaczął wzrastać po okresie akcesji Polski do Unii. Syntetycznie obrazują to tempa zmian pokazane w tabeli $1.2 \mathrm{~b}$.

Tabela 1.2b.

\section{Średnioroczne tempa zmian (w proc.) wskaźników wymienionych w tabeli 1.2a}

\begin{tabular}{|l|c|c|}
\hline \multicolumn{1}{|c|}{ Wskaźniki celu strategicznego NSRO } & $\begin{array}{c}\text { Średnioroczne } \\
\text { tempo zmian } \\
1997-2003\end{array}$ & $\begin{array}{c}\text { Średnioroczne } \\
\text { tempo zmian } \\
2004-2010\end{array}$ \\
\hline Wskaźnik zatrudnienia osób w wieku 15-64 & $-2,5$ & 2,6 \\
\hline kobiety & $-2,2$ & 2,6 \\
\hline mężczyźni & $-2,8$ & 2,6 \\
\hline Wskaźnik zatrudnienia osób w wieku 55-64 & $-2,8$ & 3,6 \\
\hline kobiety & $-2,9$ & 3,6 \\
\hline mężczyźni & $-2,8$ & 4,1 \\
\hline
\end{tabular}

Źródło: Obliczenia własne na podstawie danych z tabeli 1.2a.

Jak widać $w$ tabeli $1.2 \mathrm{~b}$ wszystkie wskaźniki zatrudnienia monitorowane w analizowanych dokumentach strategicznych notowały w okresie 1997-2003 ujemne tempa wzrostu, zaś w okresie 2004-2010 - dodatnie.

Zakładając utrzymanie tendencji z lat 2004-2010 można stwierdzić, że wszystkie, oprócz jednego, wskaźniki wymienione w tabeli 1.2a i $1.2 \mathrm{~b}$ osiagną wartości powyżej zakładanych $w$ dokumentach strategicznych, co jest oczywiście zjawiskiem pozytywnym - por. tabela 1.2c. Jedynym wskaźnikiem, dla którego prognozowana wartość leży poniżej zakładanej jest wskaźnik zatrudnienia kobiet w wieku 55-64 lata. Należy jednakże zauważyć (por. wykres 1.2b), że w latach 2006-2010 wzrost tego wskaźnika był tak intensywny, że gdyby założyć utrzymanie tendencji z tego okresu (a nie z okresu 2004-2010), wartość zakładana w NSRO nie byłaby zagrożona. 
Tabela 1.2c.

Prognozowane (na podstawie ekstrapolacji funkcji trendu z lat 2004-2010) wartości wskaźników $\mathrm{z}$ tabeli 1.2a. oraz procentowe odchylenie prognozy od wartości zakładanej w dokumentach strategicznych

\begin{tabular}{|l|c|c|c|c|c|c|}
\hline \multicolumn{1}{|c|}{ Wskaźnik } & $\begin{array}{c}\text { Prognoza } \\
2013 \text { r. }\end{array}$ & $\begin{array}{c}\text { Prognoza } \\
2015 \text { r. }\end{array}$ & $\begin{array}{c}\text { NSRO } \\
2013 \text { r. }\end{array}$ & $\begin{array}{c}\text { SRK } \\
2015 \text { r. }\end{array}$ & $\begin{array}{c}\text { Różnica } \\
2013 \text { r. }\end{array}$ & $\begin{array}{c}\text { Różnica } \\
2015 \text { r. }\end{array}$ \\
\hline $\begin{array}{l}\text { Wskaźnik zatrudnienia osób } \\
\text { w wieku 15-64 lata }\end{array}$ & 65 & 68 & 60 & 62 & $8 \%$ & $9 \%$ \\
\hline kobiety & 58 & 60 & 56,5 & 53 & $2 \%$ & $14 \%$ \\
\hline mężczyzni & 72 & 76 & 63,5 & - & $14 \%$ & - \\
\hline $\begin{array}{l}\text { Wskaźnik zatrudnienia osób } \\
\text { w wieku 55-64 lata }\end{array}$ & 38 & 40 & 35 & 37 & $8 \%$ & $9 \%$ \\
\hline kobiety & 25 & 26 & 28 & - & $-11 \%$ & - \\
\hline mężczyźni & 53 & 57 & 45 & - & $17 \%$ & - \\
\hline
\end{tabular}

Źródło: Obliczenia własne na podstawie danych z tabeli 1.2a.

\section{Wielkość i struktura zasobów pracy - stan obecny i prognozy}

Podażowa strona rynku pracy określa potencjalne zasoby pracy, wyznaczane przez ludność w wieku produkcyjnym, który w Polsce oznacza wiek 18-59 lat dla kobiet oraz 18-64 lata dla mężczyzn ${ }^{12}$. Z uwagi na posługiwanie się w porównaniach międzynarodowych i coraz częściej w Polsce, kategorią ludności $\mathrm{w}$ wieku produkcyjnym, tworzoną przez osoby będące w wieku 15-64 lata, taka definicja została przyjęta również w niniejszym opracowaniu. W Polsce prognozuje się znaczne zmiany w tej grupie osób (por. p. 2.1), które będą miały wpływ na realne zasoby pracy (por. p. 2.2), co zaznaczy się $\mathrm{w}$ wartościach wskaźników monitorowanych $\mathrm{w}$ dokumentach strategicznych (por. rozdział 3).

\subsection{Analiza i prognozy zmian w liczbie ludności}

Długofalowo, na zmiany ludnościowe oraz strukturę ludności wg wieku (które determinują podaż pracy) mają wpływ głównie wyże i niże demograficzne (ostatni boom urodzeniowy miał miejsce w latach 1981-1982),

12 Grupa wieku 0-17 lat uznana jest za wiek przedprodukcyjny, zaś wiek poprodukcyjny to 60 lat i więcej dla kobiet oraz 65 lat i więcej dla mężczyzn. 
powodując zmiany $\mathrm{w}$ procesach dzietności i umieralności, natomiast krótkofalowo oddziałują na tę strukturę zmiany w rozmiarach migracji ${ }^{13}$. Również prowadzona polityka społeczna może oddziaływać na podażową stronę rynku pracy poprzez instrumenty wpływające np. na procesy dzietności, lub w bardziej bieżącej perspektywie - poprzez politykę migracyjna, czy ogólnie politykę zatrudnienia. Jest to szczególnie istotne w przypadku Polski, gdzie liczba osób w wieku produkcyjnym ulegać będzie, zgodnie z prognozą GUS ${ }^{14}$, bardzo dynamicznemu zmniejszaniu (przy czym największy spadek będzie miał miejsce $\mathrm{w}$ pięcioleciu 2015-2020 oraz w okresach pięcioletnich bezpośrednio poprzedzających i nastęujących po tym okresie - por. wykres $2.1 \mathrm{a})^{15}$.

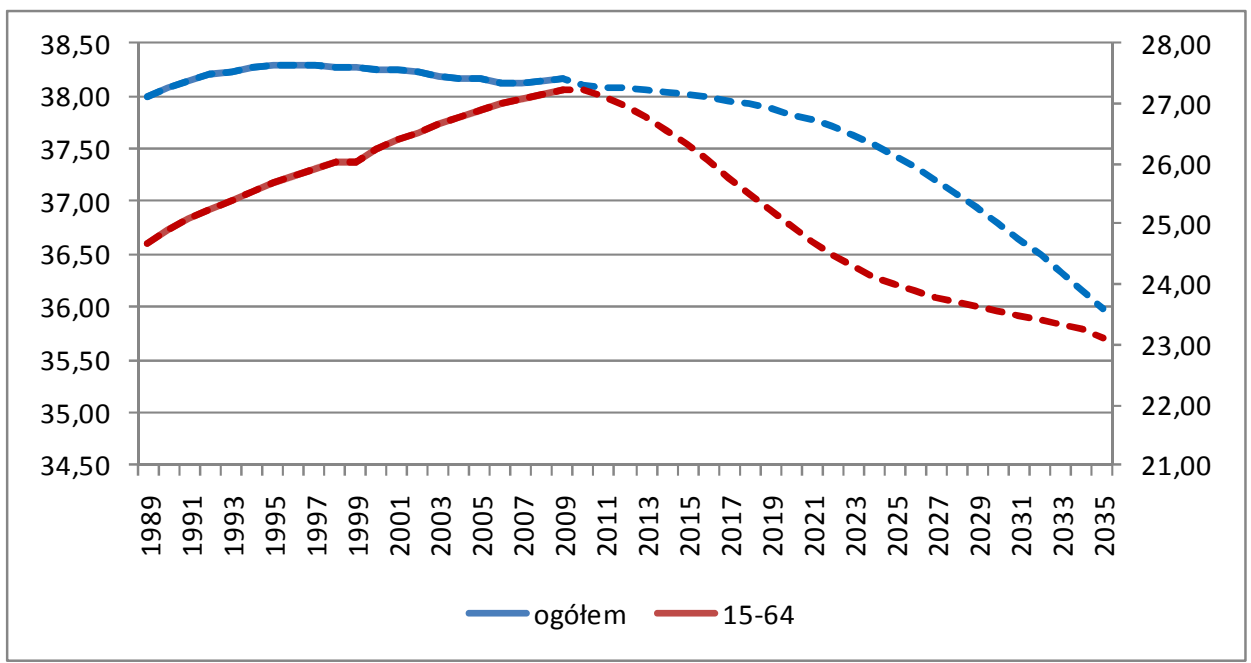

\section{Wykres 2.1a. Liczba ludności Polski ogółem (lewa oś) i w wieku 15-64 lata (prawa oś) w mln osób}

Źródło: Opracowanie własne na podstawie Prognoza ludności Polski na lata 20082035, GUS, Warszawa 2004 oraz Struktura ludności wedtug wieku latach 1989-2009, GUS.

\footnotetext{
${ }^{13}$ Por. http://www.stat.gov.pl/cps/rde/xbcr/gus/PUBL_L_prognoza_ludnosci_Pl_20082035.pdf, s. 3.

${ }^{14}$ Mamy tu na myśli Prognoze ludności Polski na lata 2008-2035.

${ }^{15}$ Wszelkie prognozy ludnościowe (zarówno na poziomie światowym/międzynarodowym opracowane przez ONZ i Eurostat, czy na poziomie lokalnym opracowane przez urzędy statystyczne poszczególnych krajów, np. GUS) wskazują na systematyczny wzrost udziału osób starszych oraz najstarszych w populacji - por. Rynek pracy $i$ wykluczenie społeczne $w$ kontekście percepcji Polaków - diagnoza spoteczna 2009, E. Kotowska (red.), Centrum Rozwoju Zasobów Ludzkich, Warszawa 2009, s. 73.
} 
Zmiany struktury ludności w wieku produkcyjnym będą dotyczyły nie tylko rozmiarów podaży zasobów siły roboczej, ale także zmian w relacji do innych grup wieku ludności ${ }^{16}$. Natomiast zmiany w liczbie osób w wieku produkcyjnym mobilnym i niemobilnym pokazane na wykresie $2.1 \mathrm{~b}$ wskazuja, że wzrośnie udział osób w wieku produkcyjnym niemobilnym oraz gwałtownie spadnie liczba osób w wieku produkcyjnym mobilnym - por. wykres $2.1 \mathrm{~b}$.

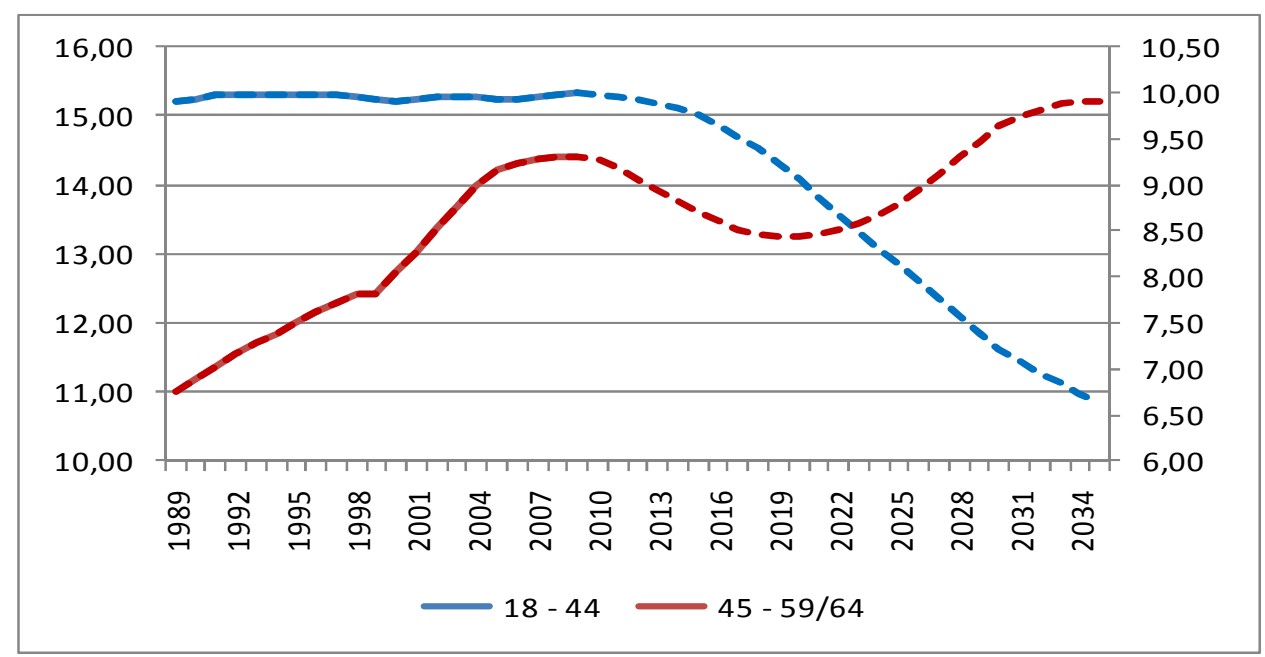

\section{Wykres 2.1b. Prognozy w dwóch grupach wiekowych w mln osób}

Źródło: Opracowanie własne na podstawie Prognoza ludności Polski na lata 20082035, GUS, Warszawa 2004 oraz Struktura ludności wedtug wieku latach 1989-2009, GUS.

Wspomniane zmiany demograficzne spowodują gwałtowne zmniejszanie się i starzenie się zasobów pracy, a w konsekwencji pogarszanie się podaży siły roboczej na polskim rynku pracy ${ }^{17}$. Należy podkreślić, że lata 2007-2010 należały do ostatnich, kiedy to trendy demograficzne sprzyjały powiększaniu

\footnotetext{
${ }^{16}$ Udział osób w wieku produkcyjnym w ogólnej strukturze ludności Polski zmniejszy się o prawie 7 punktów procentowych w perspektywie do 2035 roku, zaś osób w wieku produkcyjnym mobilnym (18-44) - zmniejszy się aż o ok. 10 pkt.

${ }^{17}$ Konsekwencje procesu starzenia się ludności mogą być nieco złagodzone zmieniającą się strukturą tych osób. Otóż można oczekiwać (por. Rynek pracy $i$ wykluczenie społeczne w kontekście percepcji Polaków - diagnoza społeczna 2009, E. Kotowska (red.), Centrum Rozwoju Zasobów Ludzkich, Warszawa 2009, op. cit., s. 73), iż „osoby starsze w przyszłości będa lepiej wykształcone niż obecnie, częściej będą miały partnerów (współmałżonków) na skutek poprawy wskaźnika umieralności, choć z drugiej strony rosnąca liczba rozwodów może mieć przeciwny efekt. Ponadto wyniki analiz stanu zdrowia osób starszych wskazują, iż można oczekiwać, że problemy zdrowotne będą się pojawiały później niż obecnie.”
} 
podaży pracy ${ }^{18}$. Od nowej dekady będziemy mieli do czynienia z malejącą liczbą osób w wieku produkcyjnym, w szczególności w wieku produkcyjnym mobilnym. Aby zapobiec skutkom malejącej podaży pracy, aktywne polityki rynku pracy powinny być nastawione na wspieranie aktywności zawodowej osób starszych, w szczególności w wieku 55+, gdzie wskaźniki aktywności i zatrudnienia są szczególnie niskie. Należy zauważyć, że w grupie starszych pracowników (45+) stopy bezrobocia są poniżej ogólnej. Oznacza to, że wspieranie aktywności zawodowej tych osób jest zagrożone mniejszym bezrobociem, niż wśród innych.

$\mathrm{Na}$ wielkość zasobów pracy, obok dzietności oraz długości życia mieszkańców, wpływ mają również migracje. „Eksperci podkreślają, że ocena sytuacji demograficznej -zwykle bardzo trudna ze względu na występowanie wielu niezsynchronizowanych zmian trendów - staje się w wypadku kraju takiego jak współczesna Polska, doświadczającego masowych migracji zagranicznych, zadaniem karkołomnym"19. Oprócz wpływu migracji na możliwości oceny przyszłych struktur demograficznych, bieżącym problemem z tego wynikającym jest fakt, że nieobecność dużej części populacji Polski może wpływać na jakość wskaźników demograficznych (osoby faktycznie nieobecne są nadal ujmowane w statystykach). Ocena skali i konsekwencji decyzji migracyjnych Polaków w literaturze przedmiotu jest wysoce zróżnicowania. Począwszy od źródeł, w których stwierdza się, że: „migracje zarobkowe to fenomen społeczny na stałe obecny w świadomości Polaków. Jak wskazują dane, w całym okresie transformacji na stałe pracowało poza Polską około miliona Polaków. Ostatnio obserwowana fala migracji (po 2004 r. - przyp. aut.) - choć niewątpliwie przyciąga uwagę mediów i pojawia się często w debacie publicznej - stanowi bardziej kontynuację tradycji, niż istotne novum w wyborach życiowych Polaków”"20, aż po alarmujące opinie, jak: „okres poakcesyjny przyniósł spektakularne i niespotykane na gruncie europejskim doświadczenie masowego odpływu za granicę (zarówno, jeśli chodzi o skalę zjawiska, jak i o jego dynamikę)"21. Należy zauważyć, że istotnym czynnikiem wpływającym na skalę migracji był okres kryzysu 2008-2009, na który Polacy zareagowali migracjami powrotnymi. Dane z Badania Aktywności Ekonomicznej Ludności „wskazują, że w kluczowym okresie między

\footnotetext{
${ }^{18}$ Należy zauważyć, że również rosnąca podaż pracy nie jest zjawiskiem jedynie pozytywnym, bowiem w przypadku Polski przyczyniła się ona w początkowym okresie (2007-2008) do wzrostu liczby bezrobotnych, ponieważ rynek nie był w stanie zaabsorbować rosnącej nagle (po wieloletnich spadkach) liczby osób gotowych pracować.

${ }^{19}$ Raport Polska 2030, Kancelaria Prezesa Rady Ministrów, Warszawa 2009, s. 78.

${ }^{20}$ P. Kaczmarczyk, J. Tyrowicz, Wspótczesne procesy migracyjne $w$ Polsce a aktywność organizacji pozarzadowych $w$ obszarach powiqzanych z rynkiem pracy, Portal Instytucji Rynku Pracy, Warszawa 2010.

${ }^{21}$ Raport Polska 2030, Kancelaria Prezesa Rady Ministrów, Warszawa 2009, s. 78.
} 
2. kwartałem 2008 a 2. kwartałem 2009 roku (decydująca była zwłaszcza pierwsza połowa 2009 roku) zasób polskich migrantów czasowych przebywających za granica zmniejszył się o około 110 tysięcy (ponad 21\%!),"22. Dane te potwierdzają informacje z raportu MPiPS, w którym czytamy, że „w 2009 r. nastąpił znaczny spadek liczby wyjazdów Polaków za granicę - zarówno na pobyt stały jak i czasowy. (...) nastapiło praktyczne zrównanie liczby emigrantów i imigrantów"23. Prawdopodobnie zatem okres największych migracji mamy już za sobą.

Migracje mogą jednak tylko nasilić lub złagodzić długofalowe trendy demograficzne, które dla Polski pokazują znaczny ubytek liczby osób w wieku produkcyjnym. Poniżej piszemy o roli tych zmian dla realnych zasobów pracy oraz poziomu aktywności zawodowej Polaków. Analiza aktywności ekonomicznej Polaków.

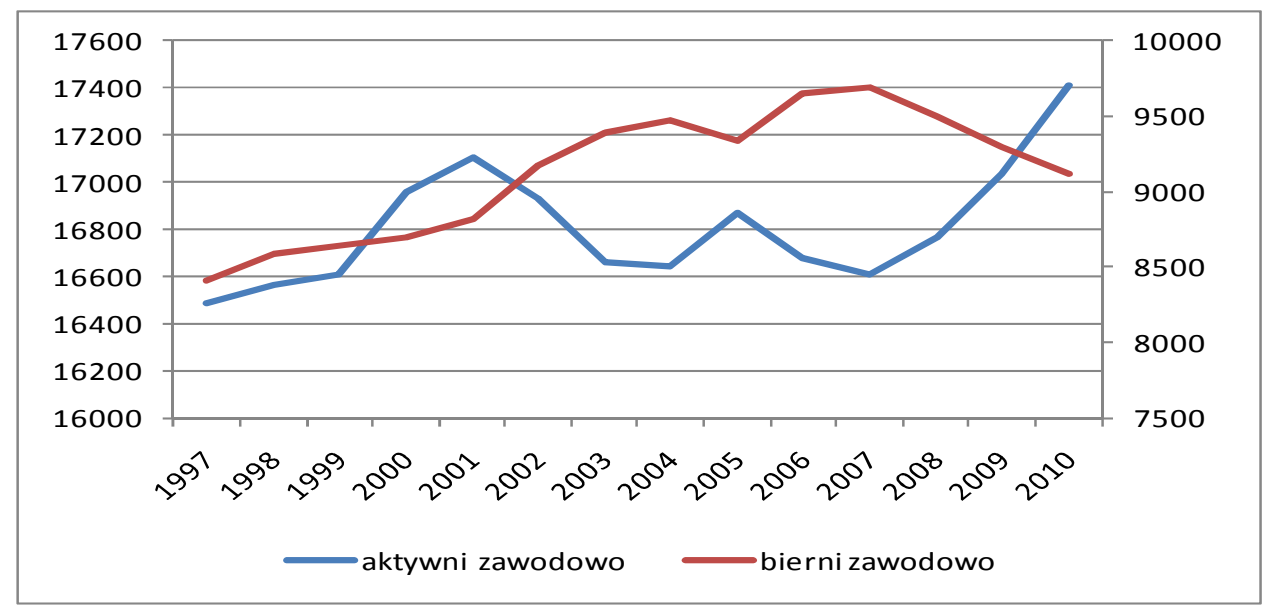

\section{Wykres 2.2a. Zmiany w liczbie osób aktywnych i biernych zawodowo} (w tys. osób)

Źródło: Opracowanie własne na podstawie:

http://appsso.eurostat.ec.europa.eu/nui/show.do?dataset=lfsa_pganws\&lang=en

\footnotetext{
${ }^{22}$ P. Kaczmarczyk, Kryzys a decyzje migracyjne Polaków, Biuletyn FISE 3/2010, s. 14.

${ }^{23}$ Polska 2010, Raport o rynku pracy oraz zabezpieczeniu spotecznym, Ministerstwo Pracy i Polityki Społecznej, Warszawa 2010, s. 5.
} 


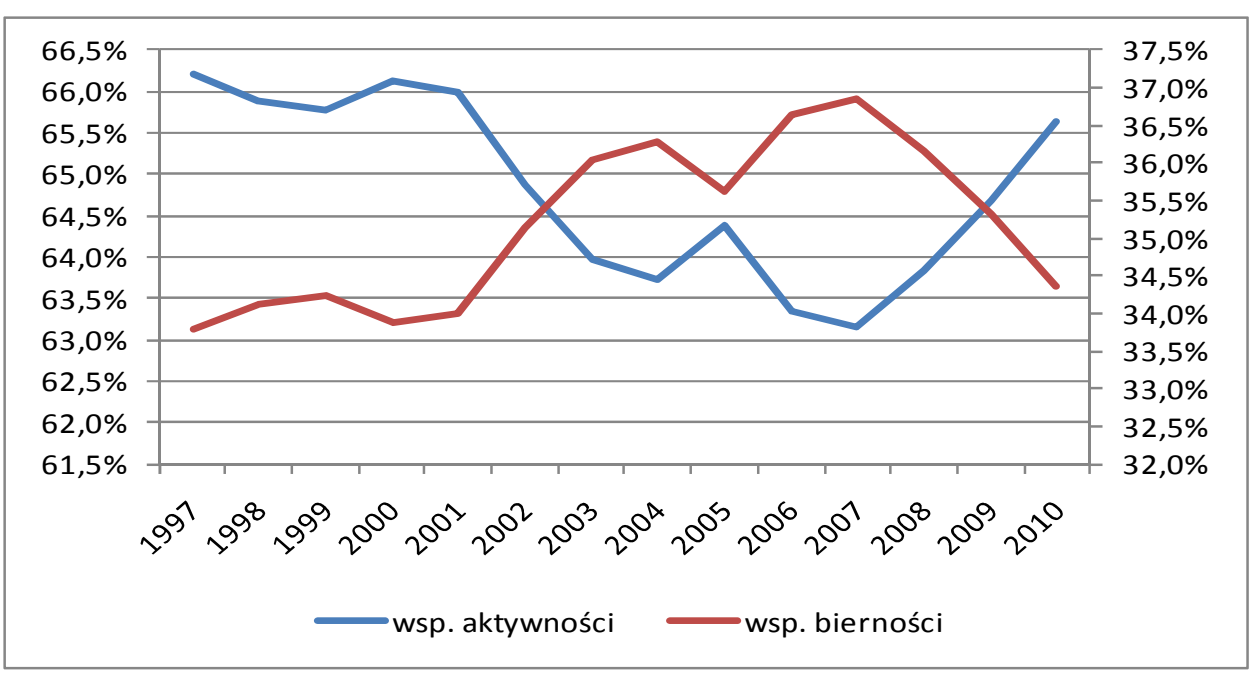

\section{Wykres 2.2b. Zmiany we współczynniku aktywności i bierności zawodowej ${ }^{24}$}

Źródło: Opracowanie własne na podstawie:

http://appsso.eurostat.ec.europa.eu/nui/show.do?dataset=lfsa_pganws\&lang=en

Potencjalne zasoby pracy tworzą osoby aktywne i bierne zawodowo ${ }^{25}$, których liczbę pokazują poniższe wykresy.

${ }^{24}$ Prezentowany w pracy współczynnik aktywności zawodowej 15-64 jest ilorazem liczby osób aktywnych zawodowo w wieku 15-64 i ogółu populacji w tym wieku. W statystyce publicznej występują różnice dotyczące liczby osób w wieku 15-64. Dla roku 2009 GUS podaje ludność $\mathrm{w}$ wieku 15-59/64 lata na poziomie 26073 tys. osób (http://www.stat.gov.pl/bdl/app/dane_podgrup.display?p_id=394479\&p_token=0.0825493719274

2512 ), ludność w wieku 15-64 rzędu 27223 tys. osób. (sumowanie pięcioletnich grup wiekowych $\mathrm{z}$ http://www.stat.gov.pl/bdl/app/dane_podgrup.display?p_id=394479\&p_token=0.1243932431511 5191). Z Eurostatu uzyskujemy wielkość populacji w wieku 15-64 rzędu 26338 tys. osób (wielkość ta jest bliższa GUS-owskiej populacji w wieku 15-59/64 niż 15-64). Liczba osób aktywnych zawodowo 15-64 wynosiła wg Eurostatu 17039 tys. osób, zaś wg GUS-u 17279 (15+) oraz 16875 (w wieku produkcyjnym). GUS nie wykazuje w BDL wskaźnika aktywności zawodowej 15-64, a jedynie aktywność 15+ oraz osób w wieku produkcyjnym. Miary te znacznie się od siebie różnią: w 2009 r. współczynnik aktywności 15+ wynosił 54,9, zaś współczynnik aktywności osób w wieku produkcyjnym 70,9. Współczynnik aktywności zawodowej 15-64 do którego odwołujemy się w niniejszej pracy wynosi 64,7 i jest ilorazem ludności aktywnej zawodowo z danych Eurostatu oraz populacji w wieku 15-64 również z Eurostatu. Takimi liczbami posługujemy się poniżej.

${ }^{25}$ Ludność aktywna zawodowo (siła robocza) obejmuje wszystkie osoby w wieku 15-64 uznane za pracujące lub bezrobotne. Ludność bierną zawodowo stanowią osoby pozostające poza siłą roboczą, są to wszystkie osoby w wieku 15-64 lat, które nie zostały zaklasyfikowane jako pracujące lub bezrobotne tzn. osoby, które w badanym tygodniu: 1) nie pracowały, nie miały pracy i jej nie poszukiwały; 2) nie pracowały, poszukiwały pracy, ale nie były zdolne (gotowe) do jej 
Z powyższych wykresów możemy odczytać, że liczba osób aktywnych zawodowo $\mathrm{w}$ okresie po akcesji do Unii najpierw malała osiagając najniższą wartość 16734 tys. osób w roku 2006 (dokładnie był to pierwszy kwartał 2007 r.) a potem rosła. Ponieważ liczba osób aktywnych zawodowo zależy od liczby osób w wieku zdolności do pracy, w celu dokonywania oceny poziomu aktywności zawodowej badanego społeczeństwa podaje się współczynnik aktywności zawodowej (udział osób aktywnych zawodowo w ogóle osób z danego przedziału wiekowego 15-64). Współczynnik ten pokazuje, że w okresie 1997-2001 rosła co prawda liczba osób aktywnych zawodowo (co stanowi głównie odzwierciedlenie tendencji demograficznych), lecz ich udział w liczbie ludności w wieku 15-64 - spadał (wzrosty liczby ludności w wieku 15-64 były silniejsze niż wzrosty liczby osób aktywnych zawodowo). Analiza współczynnika aktywności zawodowej pokazuje, że w latach 2007-2010 po raz pierwszy od okresu transformacji ustrojowej mamy do czynieniu ze zwiększeniem udziału osób aktywnych zawodowo w liczbie osób zdolnych do pracy. Utrzymanie tej tendencji wzrostowej jest jedyną możliwością utrzymania realnych zasobów pracy - o czym informuja nas analizy przeprowadzone w rozdziale 3 .

\section{Analiza polskiego rynku pracy wobec zmian demograficznych}

Jak wspomniano $\mathrm{w}$ rozdziale 2 , zgodnie $\mathrm{z}$ prognozami GUS, należy spodziewać się spadków liczby ludności w wieku zdolności do pracy. Prognozowane zmiany dla ludności w wieku 15-64 oznaczają spadki o średnio $0,9 \%$ rocznie w latach $2011-2020$ oraz dalszy spadek w tempie $0,5 \%$ rocznie w latach 2021-2030. Oczywiście fakt ten będzie miał określone konsekwencje dla statystyk rynku pracy takich jak wskaźnik zatrudnienia, czy współczynnik aktywności zawodowej. Choć konsekwencje te nie muszą być negatywne, bowiem wzrost wskaźnika zatrudnienia można osiagnąc nawet przy spadkach liczby pracujących. Wynika to z faktu, że wspomniane wskaźniki (zatrudnienia i aktywności zawodowej) są ilorazem odpowiednio liczby pracujaccych i liczby aktywnych zawodowo do ogółu ludności w danym wieku, zatem przy założeniu spełnienia się prognoz GUS co do spadków populacji w wieku 15-64, brak zmian w liczbie pracujących lub aktywnych zawodowo spowoduje wzrost wskaźnika zatrudnienia i współczynnika aktywności zawodowej - por. wykres 3.1a. Jeśli liczba pracujących i liczba aktywnych zawodowo będzie zmieniała się w tym samym tempie, co liczba ludności, wtedy wskaźnik zatrudnienia

podjęcia w ciagu dwóch tygodni następujących po tygodniu badanym; 3) nie pracowały i nie poszukiwały pracy, ponieważ miały pracę załatwioną i oczekiwały na jej rozpoczęcie w okresie: dłuższym niż trzy miesiące; - do 3 miesięcy, ale nie były gotowe tej pracy podjąć (od 2004 r.). Na podstawie: http://www.stat.gov.pl/bdl/app/slow_poje.poje_lista\#lit66. 
i współczynnik aktywności zawodowej nie będą się zmieniać - taką symulację pokazuje wykres $3.1 \mathrm{~b}$.

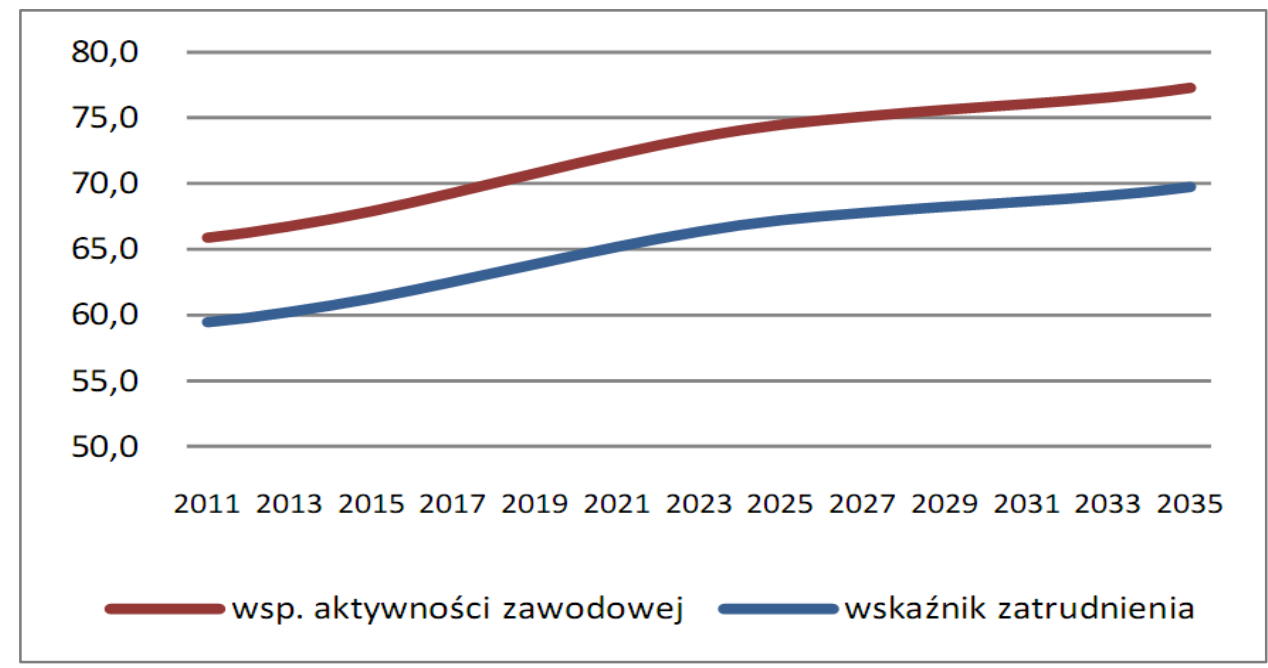

\section{Wykres 3.1a. Symulacja wartości współczynnika aktywności zawodowej oraz liczby pracujących 15-64 przy założeniu, że liczba aktywnych zawodowo oraz pracujących 15-64 będzie się utrzymywać na poziomie z roku 2010}

Źródło: Obliczenia własne na podstawie Prognoza ludności Polski na lata 2008-2035, GUS, Warszawa 2004 oraz

http://appsso.eurostat.ec.europa.eu/nui/show.do?dataset=lfsa_pganws\&lang=en

Utrzymanie liczby osób aktywnych zawodowo oraz pracujących na poziomie z roku 2010 - czyli zakładając brak zmian w tych kategoriach przy jednoczesnym spełnieniu się prognoz demograficznych GUS - powoduje, że współczynnik aktywności zawodowej rośnie do poziomu 77\%, a wskaźnik zatrudnienia osiąga wartość $70 \%$ - poziomów nienotowanych nigdy wcześniej w Polsce! $!^{26}$. Utrzymanie identycznego, z liczbą osób w wieku produkcyjnym, tempa zmian liczby osób aktywnych zawodowo oraz pracujących skutkuje „zamrożeniem” współczynnika aktywności zawodowej oraz wskaźnika zatrudnienia odpowiednio na poziomie 65,6 oraz 59,2 - sa to poziomy rekordowo wysokie jak na Polskę (i tylko nieznacznie niższe od zakładanych

\footnotetext{
${ }^{26}$ Choć są kraje, które osiagają takie poziomy tych wskaźników, np. Islandia, Szwajcaria, czy Dania. Należy też zauważyć, że postulowane dla Polski w strategii Europa 2020 wskaźnik zatrudnienia 20-64 wynosić ma w 2020 r. $71 \%$. W przybliżeniu oznacza to, że analizowany przez nas wskaźnik 15-64 miałby wynosić ok. 64,6.
} 
w dokumentach strategicznych). Powyższe przykłady są jednakże czysto hipotetyczne, chociażby ze względu na horyzont prognozy, choć pouczające (pokazują na przykład, że utrzymanie wysokiego, jak na Polskę, poziomu współczynnika aktywności zawodowej i wskaźnika zatrudnienia może odbyć się nawet przy spadkach liczby osób aktywnych zawodowo i pracujących).

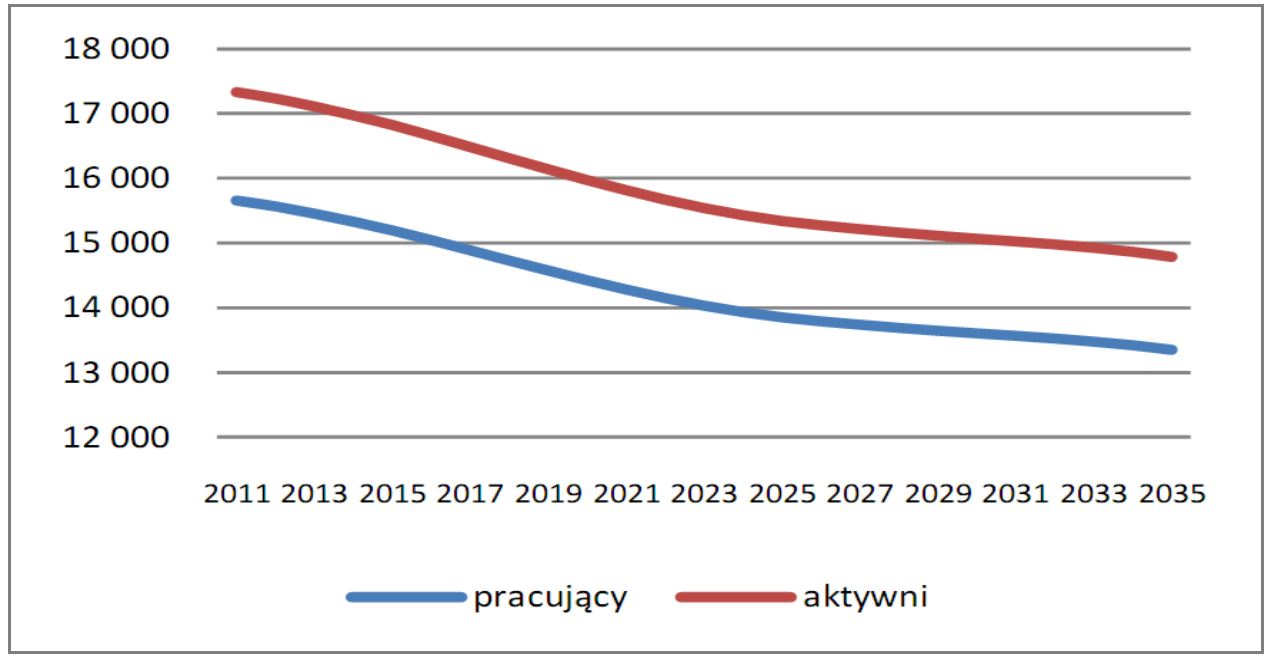

Wykres 3.1b. Symulacja liczby osób aktywnych zawodowo oraz pracujących 15-64 (w tys. osób) przy założeniu, że liczba osób aktywnych zawodowo i pracujących zmienia się w takim samym tempie co populacja w wieku 15-64

Źródło: Obliczenia własne na podstawie Prognoza ludności Polski na lata 2008-2035, GUS, Warszawa 2004 oraz

http://appsso.eurostat.ec.europa.eu/nui/show.do?dataset=lfsa_pganws\&lang=en

Trzymając się tymczasem ram czasowych wyznaczonych przez przywoływane w artykule dokumenty strategiczne: SRK i NSRO, przypomnijmy, że zakładany na 2013 i 2015 rok wskaźnik zatrudnienia 15-64 wynosi odpowiednio 60 i 62\%. Osiaggnięcie tych wartości nie będzie trudne biorąc pod uwagę bieżąca wartość: 59,2 i perspektywę kurczenia się populacji 15-64. Biorąc pod uwagę formułę liczenia wskaźników zatrudnienia (jako iloraz pomiędzy liczbą pracujących w danym wieku a ogólną liczbą osób w tym wieku) przewidywane negatywne zmiany w populacji osób zdolnych do pracy (15-64) niejako ,pomagają" w wykazywaniu pozytywnych zmian we wskaźnikach zatrudnienia zawartych w dokumentach strategicznych (wystarczy, aby tempo spadku pracujących było wolniejsze niż tempo spadku populacji 1564). Pozostaje jednakże pytanie, czy osiaganie wartości wskaźników rynku 
pracy (jak wykazaliśmy - niezbyt „forsownych”) jest wystarczające do sprostania ambitnym celom dotyczącym wzrostu zatrudnienia i podniesienia jego jakości (jeden z głównych celów realizowanej SRK).

\section{Podsumowanie}

W artykule przeanalizowano większość, monitorowanych w dwóch głównych dokumentach strategicznych rozwoju Polski, wskaźników dotyczących rynku pracy. W odniesieniu do tych wskaźników wyliczono ich prognozy - przy założeniu kontynuacji trendów z okresu po akcesji do Unii w celu pokazania, które $\mathrm{z}$ wartości postulowanych przez dokumenty strategiczne mogą być zagrożone (należą do nich np. udział pracujących w przemyśle i usługach oraz wskaźnik zatrudnienia kobiet w wieku 55-64 lata).

Należy zwrócić uwagę, że realizacja większości wskaźników rynku pracy zależy nie tylko od faktycznych zmian w zatrudnieniu, lecz również od prognozowanych zmian $w$ liczbie i strukturze ludności, czyli zmian w podażowej stronie tego rynku. $\mathrm{Z}$ jednej strony stoimy przed perspektywą bardzo gwałtownego kurczenia się zasobów pracy (szczególnie osób w wieku mobilnym), z drugiej zaś, jeśli tylko tempo tych spadków będzie wyższe niż tempo spadku pracujących, to będzie możliwe osiaganie wartości wskaźników zatrudnienia określonych $w$ strategiach krajowych. To jednak zbyt mało, aby zrealizować jednocześnie inny cel strategii rozwoju kraju dotyczący wzrostu liczby i jakości zatrudnienia.

\section{Bibliografia}

Drążkiewicz J., Gajdos A., Kołakowska Z., Kołodziej I., Kusideł E., Sochańska M., Wptyw interwencji $z$ funduszy strukturalnych UE na zatrudnienie, MRR, Warszawa 2007.

Drążkiewicz J., Gajdos A., Kusideł E., Penszko P., The impact of Cohesion Policy on the level and quality of employment in Poland, MRR, Warszawa 2010.

Drążkiewicz J., Kusideł E., Penszko P., The impact of Cohesion Policy on the level and quality of employment in countries of the Visegrad Group, MRR, Warszawa 2011.

Kaczmarczyk P., Tyrowicz J., Wspótczesne procesy migracyjne w Polsce a aktywność organizacji pozarzqdowych $w$ obszarach powiqzanych z rynkiem pracy, Portal Instytucji Rynku Pracy, Warszawa 2010.

Kaczmarczyk P., Kryzys a decyzje migracyjne Polaków, Biuletyn FISE $3 / 2010$. 
Kusideł E., Metody oceny wptywu funduszy strukturalnych na zatrudnienie, [w:] Unia Europejska w gospodarce światowej, J. Bilski (red.), Wydawnictwo Uniwersytetu Łódzkiego, Łódź 2007,

Kusidel E., The Impact of the Cohesion Policy on Poland's Economic Development, "Folia Acta Universitas Lodziensis. Folia Oeconomica", Wydawnictwo Uniwerstytetu Łódzkiego, Łódź 2011 - praca złożona do druku.

Kwiatkowski E., Teoria trzech sektorów gospodarki: prezentacja i próba oceny, PWN, Warszawa 1980.

Narodowe Strategiczne Ramy Odniesienia 2007-2013, wspierajace wzrost gospodarczy $i$ zatrudnienie, Ministerstwo Rozwoju Regionalnego, Warszawa, listopad 2006.

Olejniczak K., Rola ewaluacji w krajowych politykach publicznych - analiza systemowa lata 1999-2010, [w:] Ewaluacja w strategicznym zarzadzaniu publicznym, A. Haber (red.), Polska Agencja Rozwoju Przedsiębiorczości, Warszawa 2010.

Polska 2010, Raport o rynku pracy oraz zabezpieczeniu społecznym, Ministerstwo Pracy i Polityki Społecznej, Warszawa 2010.

Prognoza ludności Polski na lata 2008-2035, GUS, Warszawa 2004.

Raport Polska 2030, Kancelaria Prezesa Rady Ministrów, Warszawa 2009.

Rynek pracy $i$ wykluczenie społeczne w kontekście percepcji Polaków - diagnoza społeczna 2009, E. Kotowska (red.), Centrum Rozwoju Zasobów Ludzkich, Warszawa 2009.

Strategia Rozwoju Kraju 2007-2015, Ministerstwo Rozwoju Regionalnego, Warszawa, listopad 2006.

\section{ZMIANY NA POLSKIM RYNKU PRACY PO AKCESJI DO UNII EUROPEJSKIEJ I PRZYSZKE KIERUNKI ZMIAN WYNIKAJACE Z DOKUMENTÓW STRATEGICZNYCH ORAZ ZMIAN DEMOGRAFICZNYCH}

\section{Streszczenie}

W artykule podjęto dwa równoległe wątki. Pierwszym było zbadanie, czy obserwowane zmiany na rynku pracy są zgodne z kierunkami określonymi przez wskaźniki z dwóch głównych dokumentów strategicznych (SRK i NSRO, które wyznaczają kierunki rozwoju kraju) oraz sprawdzenie perspektyw ich przyszłej realizacji. Wynikiem tej części badań było stwierdzenie, że przy warunku kontynuacji 
tendencji z lat 2004-2010 większość wskaźników założonych na rok 2013 (NSRO), lub 2015 (SRK) będzie zrealizowanych.

$\mathrm{W}$ artykule wskazano również, że w osiągnięciu zakładanych wartości niektórych wskaźników równie dużą rolę, co aktywne polityki rynku pracy pełnią zmiany demograficzne - których rola była drugim wątkiem badań podjętych w artykule. Prognozy demograficzne wskazują na radykalne przeobrażanie się liczby i struktury ludności Polski, co ma niebagatelny wpływ na wybrane charakterystyki rynku pracy. Wpływ ten, paradoksalnie, nie musi być negatywny - jeśli spadki liczby ludności będą odpowiednio duże, to wzrastające poziomy wskaźnika zatrudnienia, czy współczynnika aktywności zawodowej można osiagać nawet przy spadkach liczby pracujących i liczby aktywnych zawodowo. To jednak zbyt mało, aby zrealizować jednocześnie inny cel strategii rozwoju kraju dotyczący wzrostu liczby i jakości zatrudnienia.

\title{
CHANGES IN THE POLISH LABOUR MARKET AFTER ACCESSION TO THE EUROPEAN UNION AND FUTURE DIRECTIONS OF CHANGES ARISING FROM STRATEGIC DOCUMENTS ND DEMOGRAPHIC CHANGES
}

\begin{abstract}
The article dealt with two parallel threads. The first was a study investigating whether the observed changes in the labor market were consistent with the guidelines set by indicators of the two main strategic documents (SRK and NSRF, which determine the direction of development of the country) and examined the prospects for their future implementation. The result of this part of the research determined that based on the condition of continuing the trend from the years 2004-2010, most of the indicators established in 2013 (NSRF), or 2015 (NDS) will be executed.

It is stated, however, that demographic changes, as well as active labor market policies - whose role was as the second theme of research undertaken in the article, play a big role in achieving the assumed values of certain indicators. Demographic projections indicate a radical change in the number and structure of the Polish population, which has a substantial impact on certain characteristics of the labour market. This impact paradoxically does not have to be negative. If the population decline is sufficiently large, an increase in the employment or activity rate can be achieved even with a decline in the number of the employed and economically active population. But this is not enough to simultaneously meet another goal of the country's development strategy for employment growth.
\end{abstract}

